\title{
A REDESCRIPTION OF THE SOUTH AMERICAN CATFISH LORICARIICHTHYS MACULATUS (BLOCH, 1794), WITH DESIGNATION OF THE LECTOTYPE AND RESTRICTION OF ITS TYPE LOCALITY (PISCES, SILURIFORMES, LORICARIIDAE)
}

by

\section{J. H. ISBRUCKER}

Dotterbloemstraat 5, Amsterdam-N 1019, The Netherlands

\begin{abstract}
The type species of the genus Loricariichthys Bleeker, 1862, Loricariichthys maculalus (Bloch, 1794), is redescribed from two syntypes, one of which is designated the lectotype. The same specimen is also designated the neotype for Plecostomus cataphracta Gronovius (ed. Gray), 1854 (non Loricaria cataphracta Linnaeus, 1758, sensu stricto). The type locality of both nominal species is restricted after a comparison to specimens recently collected from a locality in Surinam.
\end{abstract}

\section{INTRODUCTION}

The nomenclatural monotypic genus Loricaria Linnaeus, 1758, was originally diagnosed from two widely different biological species, called Loricaria cataphracta by Linnaeus in 1758. By common consent, the species described as "Loricaria dura" by Linnaeus in 1754 (pre-Linnaean) became in almost all literature nomenclaturally fixed as representing the Loricaria cataphracta. The other species was named Loricaria maculata by Bloch in 1794. This specific name was accepted by all subsequent authors except Gronovius, who, in his posthumous work (edited by Gray) of 1854 restricted the specific name cataphracta (in the genus Plecostomus) to the fish he first described as "Plecostomus no. 68 " in 1754. It has been accepted, even by Bloch, that the first description on which the Plecostomus cataphracta of Gronovius (1854) was based, viz. his "Plecostomus no. 68" (1754) refers to the same species that Bloch described as Loricaria maculata, and the present author agrees. Bloch did not mention a locality for his new species; Gronovius, however, recorded Surinam as the locality for his "Plecostomus no. 68". Although Gronovius' material is no longer extant, from both his de- scription and figures there is no doubt what species was involved. To further nomenclatural stability, the lectotype of Loricaria maculata is designated simultaneously the neotype for Plecostomus cataphracta Gronovius, 1854, the latter thus automatically becoming an objective junior synonym of the former. The presence of Loricariichthys maculatus in Surinam has been recorded in several works on the group, and to me it appeared relevant to restrict the type locality to a place in Surinam.

In 1862 Bleeker established the generic name Loricariichthys, with Loricaria maculata Bloch, 1794 , as the type species, by original monotypy. This generic name has been used many times in ichthyological nomenclature, but not always correctly. So the present concept of Loricariichthys might confuse the worker who attempts to classify certain loricariid fishes.

The main purpose of the present paper is to redescribe the type species of the genus (which from a systematic point of view is as valid as Loricaria) in its most limited sense, viz., from type specimens, supplemented with specimens from the type locality. Employing recently obtained material from Surinam which has been found identical to Bloch's original type specimens (which are redescribed), it was possible to restrict the type locality, as a starting point towards a revision of the genus.

\section{MEASUREMENTS}

In the description of the specimens the a $\mathrm{x}$ i a 1 l e $\mathrm{ng} t \mathrm{~h}$ equals the standard length plus the length of the middle caudal fin rays or the membrane between them; the head length is from the 

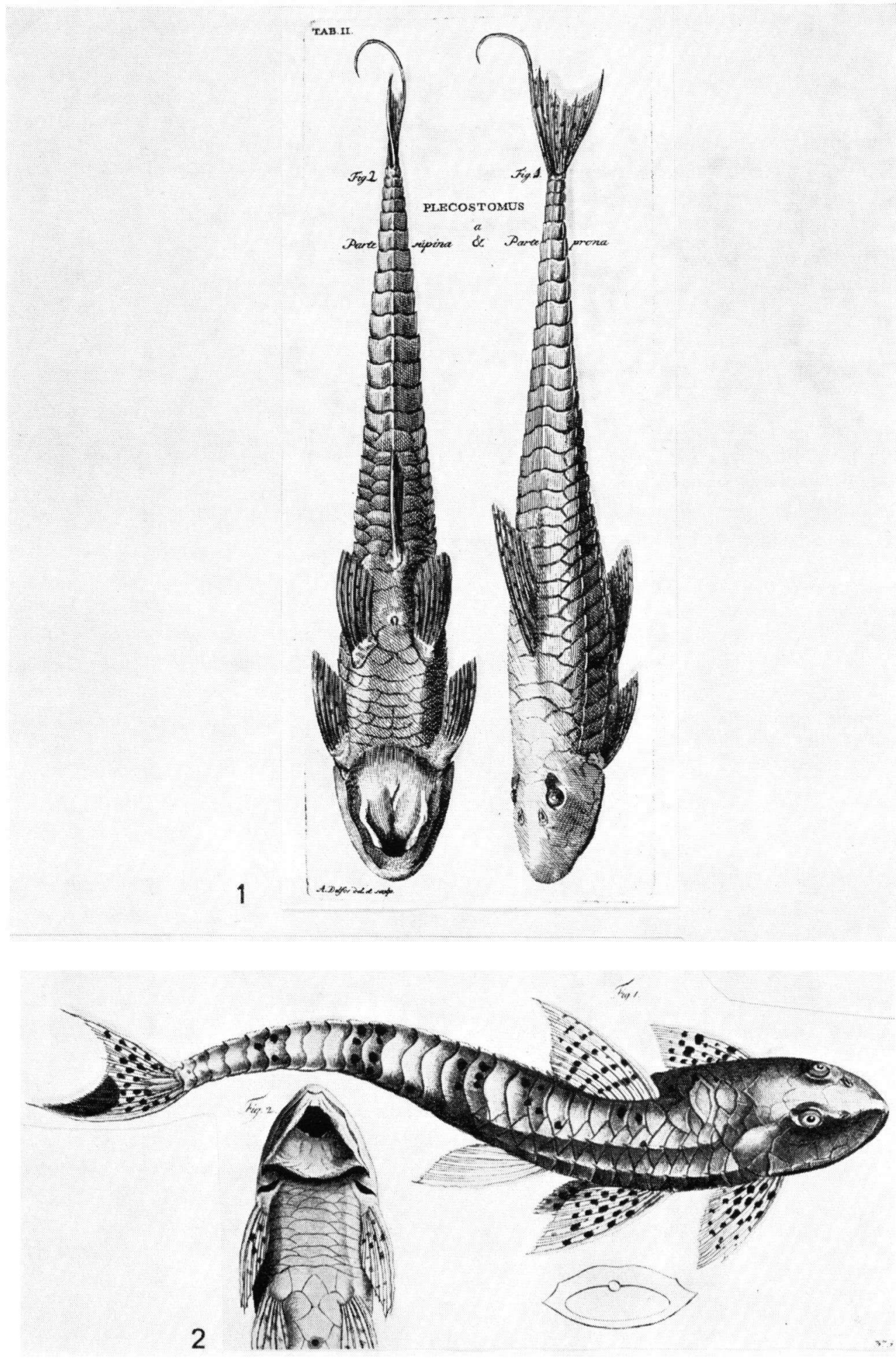

Fig. 1. Reproduction of Gronovius" (1754) figures of "Plecostomus no. 68".

Fig. 2. Reproduction of Bloch's (1794) figures of Loricaria maculata. 
tip of the snout to the end of the occipital process; the head width is taken at the opercle, just before the pectoral fin spine insertion; the $\mathrm{h}$ e a d $\mathrm{dep} t \mathrm{~h}$ is taken at the end of the occipital process; the snout length is from the tip of the snout to the anterior border of the orbital rim; the thoracic length is taken between the spine insertions of the pectoral and pelvic fins; and the abdominal length is taken between the spine insertions of the pelvic and anal fins. All other measurements are self-explanatory. The measurements were taken directly.

\section{Loricariichthys maculatus (Bloch, 1794)}

$$
\text { (figs. 1-7) }
$$

Type locality, by present restriction. - Surinam (formerly Dutch Guiana): district Suriname, ditches at Cultuurtuin (= Botanical Gardens) at Paramaribo West $\left(05^{\circ} 50^{\prime} \mathrm{N}, 55^{\circ} 10^{\prime} \mathrm{W}\right)$.

Loricaria cataphracta; Linnaeus, $1758: 307$ (in part, sensu lato [non Loricaria cataphracta Linnaeus, 1758 307 , sensu stricto]; in the original diagnosis of 'variant' "1"; reference to 'Plecostomus no. 68" Gronovius, 1754, and diagnosis). - Linnaeus (ed. Gmelin), 1789: 1363 (same as preceding).

Loricaria maculata Bloch, 1794 : 73-75, pl. 375 figs. 1-2 (original description; no locality mentioned; lectotype in Zoologisches Museum an der Humboldt-Universität zu Berlin, ZMB 3163).

Loricaria Cirrhosa var. Maculata; Bloch \& Schneider, 1801: xxxii (in index), and page 125 (diagnosis, after Loricaria maculata Bloch, 1794).

Plecostomus maculatus; Swainson, 1839 : 304 (in part; diagnosis, after copied data).

Loricariichthys maculatus; Bleeker, 1862a : 3 (generic diagnosis; type species, by original monotypy, of the new genus).

Plecostomus cataphracta Gronovius (ed. Gray), 1854: 158 [non Loricaria cataphracta Linnaeus, 1758, sensu stricto]; (in the present paper considered the original diagnosis of a new species, after "Plecostomus no. 68" Gronovius, 1754; neotype in Zoologisches Museum an der Humboldt-Universität zu Berlin, ZMB 3163).

"Plecostomus no. 68" Gronovius, 1754 : 25-26, pl. 2 figs. $1-2$ (pre-Linnaean and non-binominal, therefore nomenclaturally invalid; description; Surinam).

"Plecostomus no. 391" Gronovius, 1763 : 127, pl. 2 figs. 1-2 (non-binominal, therefore nomenclaturally invalid; diagnosis, after "Plecostomus no. 68" Gronovius, 1754).

Material examined. - ZMB 3163, lectotype ${ }^{1}$ ), by present designation, of Loricaria maculata Bloch, 1794, a $\delta$, $214.0 \mathrm{~mm}$ standard length, South America (probably

1) See also discussion.
Surinam), collected by M. E. Bloch, end of the 18th century; at the same time, this specimen is the neotype ${ }^{1}$ ) for Plecostomus cataphracta Gronovius (ed. Gray), 1854 (in Museum für Naturkunde der Humboldt-Universität zu Berlin). - ZMB 22224, paralectotype ${ }^{1}$ ) of Loricaria maculata Bloch, 1794, sex unknown, $109.0 \mathrm{~mm}$ standard length, same data as ZMB 3163, and at the same time, this specimen is the paraneotype ${ }^{1}$ ) for Plecostomus cataphracta Gronovius (ed. Gray), 1854. - ZMA 109.846 and ZMA 109.847, a $\delta, 163.0 \mathrm{~mm}$ standard length and a $\%, 175.0 \mathrm{~mm}$ standard length, respectively, topotypes, Surinam, district Suriname, ditches at Cultuurtuin at Paramaribo West $\left(05^{\circ} 50^{\prime} \mathrm{N}, 55^{\circ} 10^{\prime} \mathrm{W}\right)$, collected by $\mathbf{H}$. Nijssen (Brokopondo Research 1966/1967 2)), 12-XII1966. - ZMA 105.307, 35 specimens, topotypes, same data as ZMA 109.846 and ZMA 109.847.

The following description is based on $\mathrm{ZMB}$ 3163 (a $\left.\sigma^{*}\right)$, ZMB 22224 (a juvenile), ZMA 109.846 (a $\left.\sigma^{\circ}\right)$, and ZMA 109.847 (a $\%$ ). Morphometric and meristic data: standard length $214.0,109.0,163.0,175.0 \mathrm{~mm}$; axial length 234.5 , $119.5,181.2,192.8 \mathrm{~mm}$; total length damaged, damaged, damaged, $211.2 \mathrm{~mm}$; predorsal length $66.1,33.0,53.7,54.8 \mathrm{~mm}(3.2,3.3,3.0,3.2$ in standard length); head length $44.7,22.2,36.3,36.0$ mm (4.8, 4.9, 4.6, 4.9 in standard length); head width $33.5,16.4,27.8,29.5 \mathrm{~mm}(6.4,6.7,5.9,5.9$ in standard length, $1.3,1.4,1.3,1.2$ in head length); head depth $18.4,8.7,14.6,16.0 \mathrm{~mm}$ (11.6, $12.5,11.2,10.9$ in standard length, 2.4, 2.5, 2.5, 2.3 in head length); snout length $22.4,10.2,18.9$, $18.6 \mathrm{~mm}(9.6,10.7,8.6,9.4$ in standard length, $2.0,2.1,1.9,1.9$ in head length); orbital diameter $7.3,4.4,6.4,6.0 \mathrm{~mm}(6.1,5.0,5.7,6.0$ in head length); interorbital width $10.0,4.6,8.6,8.8 \mathrm{~mm}$ (4.5, 4.8, 4.2, 4.1 in head length); internasal width $7.3,4.0,6.6,6.3 \mathrm{~mm}(6.1,5.6,5.5,5.7$ in head length); dorsal spine length 44.0, 26.1, 41.5, 42.0 $\mathrm{mm}(4.9,4.2,3.9,4.2$ in standard length); length first dorsal ray 42.5, 25.0,38.8, $40.2 \mathrm{~mm}(5.0,4.4$, $4.2,4.4$ in standard length, $1.1,0.9,0.9,0.9$ in head length); length last dorsal ray 18.8, 8.7, 15.4, $15.0 \mathrm{~mm}(11.4,12.5,10.6,11.7$ in standard length, 2.4, 2.5, 2.4, 2.4 in head length); length dorsal fin base $18.8,10.0,15.4,17.1 \mathrm{~mm}(11.4,11.0,10.6$, 10.2 in standard length, 2.4, 2.2, 2.4, 2.1 in head length); anal spine length $36.9,19.0,31.0,>32.0$ $\mathrm{mm}(5.8,5.7,5.3,<5.5$ in standard length, 1.2 ,

2) The Brokopondo Research Project, biological investigations in the artificial "Prof. Dr. Ir. W. J. van Blommestein Lake" (= Brokopondo Lake) in the Suriname River ( $8 \mathrm{~km} \mathrm{~S}$. of Brokopondo), Surinam; sponsored by the Netherlands Foundation for the Advancement of Tropical Research. Cf. Nijssen \& Isbrücker, 1967, 1968; Mees, 1967; Boeseman, 1968, 1969; Nijssen, 1970. 

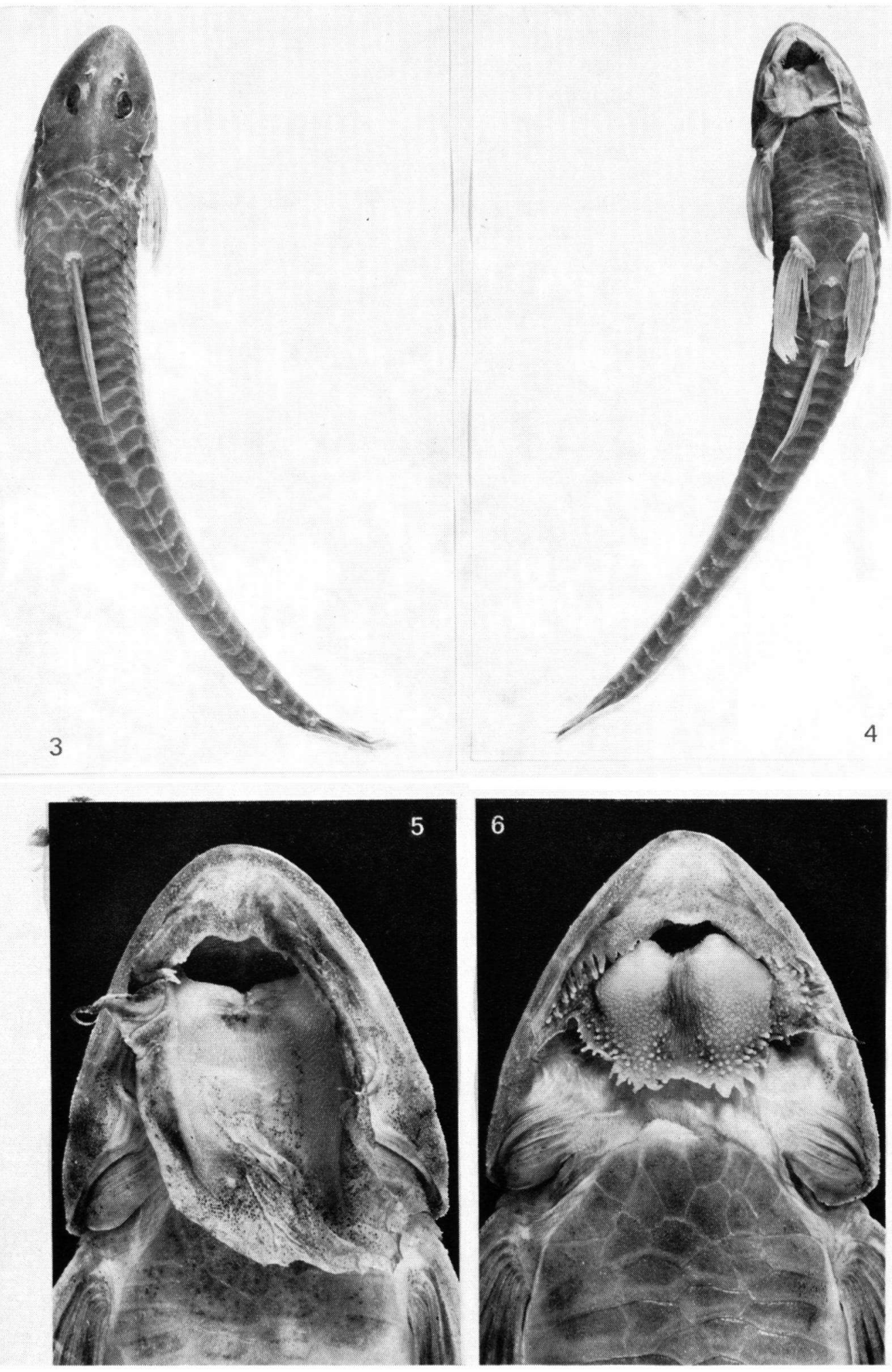

Figs. 3-6. Loricariichthys maculatus. 3, lectotype in dorsal view; 4, lectotype in ventral view; 5, topotype ( $\delta$ ), ZMA 109.846; 6, topotype ( $($ ), ZMA 109.847 (notice secondary sexual dimorphism in the lips in figs. 5 and 6). 
$1.2,1.2,<1.1$ in head length); pectoral spine length $34.3,15.3,28.2,28.4 \mathrm{~mm}(6.2,7.1,5.8,6.2$ in standard length, 1.3,1.5, 1.3, 1.3 in head length); pelvic spine length $38.9,18.3,30.1,33.0$ $\mathrm{mm}(5.5,5.9,5.4,5.3$ in standard length, $1.1,1.2$, $1.2,1.1$ in head length); length upper principal caudal 'spine' (unbranched ray) damaged, damaged, damaged, $36.6 \mathrm{~mm}$; length lower principal caudal 'spine' (unbranched ray) damaged, 15.0, 24.4 , damaged, $\mathrm{mm}(? . ?, 7.3,6.7, ? . ?$, in standard length, ?.?, 1.5, 1.5, ?.?, in head length); cleithral width $32.0,16.6,26.6,28.3 \mathrm{~mm}(6.7,6.6,6.1,6.2$ in standard length, 1.4, 1.3, 1.4, 1.3 in head length); supracleithral width $26.3,13.3,20.8,21.9 \mathrm{~mm}(8.1$, $8.2,7.8,8.0$ in standard length, $1.7,1.7,1.7,1.6$ in head length); thoracic length $21.1,9.5,16.1$, $15.1 \mathrm{~mm}(10.1,11.5,10.1,11.5$ in standard length, 2.1, 2.3, 2.3, 2.4 in head length); abdominal length $32.3,15.3,25.8,27.0 \mathrm{~mm}(6.6,7.1,6.3,6.5$ in standard length, 1.4, 1.5, 1.4, 1.3 in head length); post-anal peduncular length 110.0, 57.4, 80.0, 89.0 mm $(1.9,1.9,2.0,2.0$ in standard length); depth caudal peduncle $3.8,1.6,2.7,2.7 \mathrm{~mm}(11.8,13.9$, $13.4,13.3$ in head length); width caudal peduncle $7.5,3.8,6.8,6.6 \mathrm{~mm}(6.0,5.8,5.3,5.5$ in head length); distance between anus and anal fin origin $16.2,9.6,13.2,14.8 \mathrm{~mm}(13.2,11.3,12.3,11.8$ in standard length, 2.8, 2.3, 2.7, 2.4 in head length); length longest barbel of the upper lip 29.3, 10.2, $22.0,19.6 \mathrm{~mm}(7.3,10.7,7.4,8.9$ in standard length, $1.5,2.2,1.6,1.8$ in head length); greatest axial length of the lower lip 23.0, 5.5, 22.2, 10.2 $\mathrm{mm}(1.9,4.0,1.6,3.5$ in head length); barbels along the edge of the lower lip absent in males, small in females.

Body scutes in longitudinal lateral series 33,32 , 32,32 , last scute on caudal peduncle. Scutes between dorsal spine and caudal fin 27, 27, 27, 26. Scutes between anal fin origin and caudal fin 23 , $22,22,22$. Post-occipital scutes 2 in all four specimens, predorsal shield not included. Between anus and anal fin origin 3 pairs of scutes in all four specimens, an anal plate present. On the thorax, between the last pectoral fin ray and the pelvic fin spine (left/right) 5/4,3/3,5/4, 5/4 oblong scutes are present. The belly is completely covered by large platelets between the oblong thoracic scutes (figs. 1, 2, and 4).

Dorsal fin I,6, last ray split to its base; anal fin $I, 4$, last ray split to its base; pectoral fin I,6; pelvic fin I,5; principal caudal fin 'spines' and rays I,10,I. Fin counts are equal in all four specimens.

Two long rictal barbels with about 8-12 very
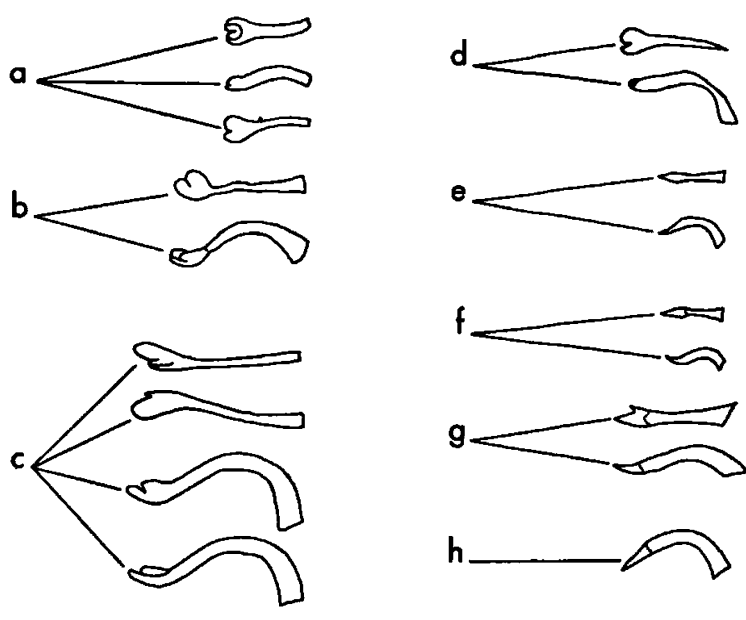

$1 \mathrm{~mm}$

Fig. 7. Loricariichthys maculatus. Profiles of the teeth from: a, upper jaw of the lectotype, b, lower jaw of the lectotype, c, lower jaw of the $\delta$ topotype, $d$, upper jaw of the $\delta$ topotype, e, upper jaw of the paralectotype, $f$, lower jaw of the paralectotype, g, lower jaw of the $q$ topotype, h, upper jaw of the $\$$ topotype. Each letter represents a single tooth.

short subbarbels, or large papillae. Upper jaw with (left/right) ?8/?8, ?4/?, 5/5, 5/10 rudimentary small teeth (found to be disarranged and difficult to count in the old specimens) and lower jaw with (left/right) 6/9.9/5, 12/9, 8/12 small teeth. There is a considerable variation in teeth shape, as shown diagramatically in fig. 7 . In the lectotype and in the male topotype the teeth in both jaws are bilobed, each lobe is spoon shaped. Viewed from the front the lobes are at an angle to each other. In the paralectotype the teeth in both jaws are spatula shaped. In the female topotype the teeth in the upper jaws resemble those of the paralectotype, whereas the teeth in the lower jaws are bifid. Some teeth removed for examination.

Eye round, the pupil partly covered by a flap originating from the iris. The flap does not reach the ventralmost inner edge of the iris and is rounded below. A deep posterior notch is present. Dermal ossifications, spines and rays of the fins are covered by minute denticles. There are two distinct ridges along the lateral body scutes, coalescing on the (left/right) 18th/18th, 18th/19th, 18th/ 18 th, 18th/18th scute. There are some inconspicuous ridges on the predorsal scutes in the paralectotype, not present in the adult specimens. Denticles are lacking in a narrow area along the snout profile. This area is bordered ventrally by 
the ventral snout margin, covered by denticles.

Irregular structure of platelets covers head and snout dorsally, well visible in the old specimens, but less distinct in the topotypes. The spines of the fins are slender, terminally flexible and slightly thicker than adjacent rays. Sensory canal system well developed, both on the head and between the two lateral ridges of denticles. Most of the sensory canals between the lateral body scutes are bifurcated.

The lower lip of the males is large, the entire surface being covered by minute, regularly sized papillae. There are two fleshy, rectangular flaps, devoid of papillae, in the buccal cavity, just below the upper jaws. The lower lip of the females is smaller. Small papillae are present on 'cushions', increasing in size towards the edges, and becoming barbel-like along the edge (fig. 6). The important sexual dimorphism in the lower lip is functional; the male is known to take care of the eggs (Menezes, 1949, for Loricaria typus (Bleeker, 1862) [this species is said to be identical to Loricariichthys maculatus]); at the type locality of Loricariichthys maculatus Dr. Nijssen collected one male specimen carrying eggs under the lower lip. The two flaps in the buccal cavity of the female are larger than in the male and have distinct papillae.

Colour (in alcohol). - Ground colour brownish grey dorsally, dirty yellow ventrally. There are three faint transverse bands on the dorsal side, viz., (1) at the seventh, (2) at the twelfth to fourteenth, and (3) at the seventeenth to eighteenth lateral body scute. A few dark brown spots, irregularly distributed on the body. Spines and rays with a regular series of dark grey spots, except in the anal fin spine and rays. A large, faint brownish grey blotch in the terminal third of the lower caudal fin lobe (fig. 2). Lips with greyish pigmentation. Traces of the original colour pattern are still present in the lectotype and paralectotype.

\section{DISCUSSION}

Nomenclatural remarks. - The first account of the species Loricariichthys maculatus was published by Gronovius (1754: 25-26, pl. 2 figs. 1-2) under the description of "Plecostomus no. 68". The species was diagnosed as "PLECOSTOMUS dorso monopterygio, ore cirrato, edentulo, ossiculo superiori caudae bifurcae setiformi brevi." On page 26 Gronovius stated the locality: "Inhabitat Surinamae flumina". His fairly complete account con- tained two errors. First, his reference to "Plecostomus corpore aculeato, ore cirrato, dorso monopterygio. Arted. mss. ad Sebam." should have been placed under the description of Gronovius' "Plecostomus no. 69" [ = Loricaria cataphracta Linnaeus, 1758, sensu stricto]. Although Seba's (1758, pl. 29 fig. 14) figure resembles superficially Loricariichthys maculatus rather than Loricaria cataphracta (s.s.), it is evident from his descriptions (page 88, in Latin and Dutch) that he had a fish closely related or identical to the species known today as Loricaria cataphracta Linnaeus, 1758. Second, Gronovius stated in both the diagnosis and in the description ("Dentes in labiis nulli conspicui.") that "Plecostomus no. 68" was toothless.

The original diagnosis by Linnaeus (1758: 307-308) of Loricaria cataphracta (type species, by original monotypy, of Loricaria Linnaeus, 1758) reads:

cataphracta 1. Loricaria. Mus. Ad. Fr. 1. p. 79. t. 29. f. 1. D. $1 / 8$. P. $1 / 7$. V. $1 / 6$. A. $1 / 6$. C. 12 . Gron. mus. 1. n. 68. t. 2.

f. 1.2. Plecostomus dorso monopterygio, ossiculo superiori caudae bifurcae setiformi.

D. $1 / 8$. P. $1 / 7$. V. $1 / 6$. A. 6. C. 12.

B. Gron. mus. 1. n. 69. Plecostomus ore edentulo, ossiculo superiori caudae bifurcae longitudine corporis. Habitat in America meridionali.

Lobus superior caudae filo longissimo terminatur.

This diagnosis consists of three parts. The first part refers to Linnaeus' own (1754) description and figure of "Loricaria dura", the second part to Gronovius' (1754) description and figures of "Plecostomus no. 68", and the third part to Gronovius' (1754) description of "Plecostomus ne. 69". Both "Loricaria dura" and "Plecostomus no. 68" represent equivalent parts of the diagnosis eligible to type selection, because Linnaeus referred "Plecostomus no. 69" to the $\beta$-variety of Loricaria cataphracta. "Loricaria dura" and "Plecostomus no. 68" differ at generic level, whereas "Loricaria dura" and "Plecostomus no. 69" in all probability referred to the same species. Bloch was the 'first revisor' of this diagnosis (in a post-Linnaean and binominal work), and he restricted in 1794 the name Loricaria cataphracta to the species Linnaeus described as "Loricaria dura", whereas he also described the same species as Gronovius' "Plecostomus no. 68", naming it Loricaria macu. lata.

Gronovius (ed. Gray), in 1854, however, retain- 
ed the generic name Plecostomus ${ }^{3}$ ). He named his "Plecostomus no. 68" Plecostomus cataphracta, and his "Plecostomus no. 69" Plecostomus flagellaris. Although the origin of the specific name Plecostomus cataphracta Gronovius, 1854, is obvious, I propose to consider it a new Gronovian name instead of a quoted Linnaean (1758) name. Plecostomus cataphracta is a synonym of Loricariichthys maculatus, and not a homonym of Loricaria cataphracta. Since the material on which Gronovius based his Plecostomus cataphracta is no longer extant (cf. Wheeler, 1958), I propose, to further nomenclatural stability, to designate the lectotype of Loricaria maculata Bloch, 1794 (= Loricariichthys maculatus), at the same time the neotype of Plecostomus cataphracta Gronovius, 1854, the latter becoming an objective junior synonym of Loricariichthys maculatus. One is inclined to refer to article $75 \mathrm{~b}$ of the International Code (1964 : 81 : “CASES EXCLUDED. - A neotype is not to be designated ... for a species of which the name is not in general use either as a valid name or as a synonym"). However, it seems relevant to designate a neotype for Plecostomus cataphracta Gronovius, 1854 , because of its easy confusion with the name Loricaria cataphracta Linnaeus, 1758.

As the lectotype I chose the largest of the two still extant syntypes, most probably it is the specimen figured by Bloch. Dr. C. Karrer (in litt., May 26th, 1970) stated: "Vielleicht nützt es Ihnen, zu wissen, dass Bloch von $L$. maculata ..., ursprünglich 4 Exemplare besessen hat, jetzt aber nur noch die beiden vorhanden sind." The smaller syntype, becoming the paralectotype, is consequently designated the paraneotype of Plecostomus cataphracta Gronovius, 1854. Although rarely (may be never) terms like paraneotype (and alloneotype) are applied in systematic works, the accepted use of the terms holotype, allotype, and paratype on the one hand and lectotype and paralectotype on the other hand, induce me to introduce equivalent terms for the neotype series, too.

\section{COMMENTS ON THE SYNONYMY OF LORICARIICHTHYS MACULATUS}

I should like to make some remarks on the proposed synonymy of Loricariichthys maculatus, because

3) At present a synonym of Hypostomus Lacépède, 1803, type species, by original monotypy, Hypostomus guacari Lacépède, 1803, to be identified with Acipenser plecostomus Linnaeus, $1758=$ Hypostomus plecostomus (Linnaeus, 1758); fide Boeseman, 1968. of the existence of the name Parahemiodon typus, a nominal species first described by Bleeker from Surinam in 1862. The specific name typus (in connection with either Parahemiodon, or Loricaria, or Loricariichthys) has been accepted as representing a valid species up to 1946. Van der Stigchel (1946 : 172-174) listed the single known specimen together with his material of Loricaria maculata 4) and stated on pages 173-174: "In the specimens no. 3121 [RMNH 3121, the holotype of Parahemiodon typus] and 10723 the lower lip is much larger than in the others. Bleeker has brought the specimen 3121 to a new species, called Parahemiodon typus, but I think that the difference is due to sexual variation; that their fins are longer and broader has, in my opinion, the same reason. In no. 10723 the first spine of the dorsal, pectorals, ventrals and anal is somewhat prolonged and stronger than in the other specimens; also the ventral buckler is larger and heavier. In the specimen described by Bleeker this was impossible to state, because the fins are badly damaged. I have, therefore, brought maculata and typus to the same species." It is dangerous to follow Van der Stigchel without having examined the holotype of Parahemiodon typus. If Regan (1904 : 287) should be followed in his synonymy of Loricaria (Loricariichthys) typus (Bleeker, 1862), Loricaria valenciennesi Vaillant, 1880, and Loricaria stubelii [more correctly spelled as $L$. stuebeli] Steindachner, 1882, and if Eigenmann and Eigenmann (1889: 39) were right in their proposed synonymy of Loricaria (Loricariichthys) konopickyi Steindachner, 1879, and Loricaria valenciennesi Vaillant, 1880, all these specific names would refer to Loricariichthys maculatus (Bloch, 1794), when the synonymy of Loricaria maculata and Parahemiodon typus, as proposed by Van der Stigchel, would be included 5). However, I have examined the holotype of Loricaria valenciennesi (MNHN A. 1985), and this species certainly is not identical to Loricariichthys maculatus (Bloch, 1794): it neither represents a species of Loricaria, nor of Loricariichthys. A re-examination of all the type material of the species of the Loricariinae will be necessary before any conclusion on the synonymy can be drawn. For the same reason the references listed above are nothing but primary.

4) Van der Stigchel also recorded a specimen from the "Botanical Garden, Paramaribo", the type locality.

5) Loricaria amazonica de Castelnau, 1855, also has been considered a synonym of Loricariichthys maculatus by almost all authors. 


\section{ACKNOWLEDGEMENTS}

I would like to express my thanks to the following persons, who were helpful in the preparation of this paper: to Mrs. Dr. M. L. Bauchot (Muséum National d'Histoire Naturelle, Paris, MNHN) for the loan of some loricariid fishes, including the holotype of Loricaria valenciennesi Vaillant, 1880; to Mr. M. C. Burns (Cheltenham, England) for kindly correcting the English; to Prof. Dr. K. Deckert and Dr. C. Karrer (Museum für Naturkunde der Humboldt-Universität, Berlin, ZMB) for the loan of the two syntypes of Loricaria maculata Bloch, 1794, for the permission to designate the lectotype, and for information; to Mr. A. L. van der Laan (Instituut voor Taxonomische Zoölogie ("Zoölogisch Museum"), Amsterdam, ZMA) for making the photographs and reproductions; to Dr. H. Nijssen (also ZMA) for his criticism and advice; and to Mrs. Drs. F. F. J. M. Peeters-Pieters (Artis Bibliotheek, Universiteit van Amsterdam) for tracing the many valuable publications in her care. The study was done at the Department of Ichthyology of the Institute of Taxonomic Zoology ("Zoölogisch Museum"), Amsterdam; fig. 7 was made by the author.

\section{LITERATURE}

Bleeker, P., 1862a. Atlas ichthyologique des Indes Orientales Néerlandaises: Siluroïdes, Chacoïdes et Hétérobranchoïdes, 2 : 1-112, pls. 49-101 (Fr. Muller, Amsterdam) [May].

,$- 1862 b$. Descriptions de quelques espèces nouvelles de silures de Suriname. Versl. Meded. Kon. Akad. Wetensch., 14 : $371-389$ [June].

-, 1863. Systema Silurorum Revisum. Ned. Tijdschr. Dierk., 1 : 77-122.

-, 1864. Description des espèces de silures de Suriname, conservées aux musées de Leide et d'Amsterdam. Natuurk. Verh. Holl. Maatsch. Wetensch. Haarlem, (2) $20: 1-104$, pls. $1-16$.

Bloch, M. E., 1794. Allgemeine Naturgeschichte der ausländischen Fische, $8: 1-174$, pls. 361-396 ( Allgemeine Naturgeschichte der Fische, 11).

Bloch, M. E. (in J. G. SchNeIDER, editor), 1801. Systema Ichthyologiae: i-1x, 1-584, pls. 1-110 (Berolini).

Boeseman, M., 1968. The genus Hypostomus Lacépède, 1803 , and its Surinam representatives (Siluriformes, Loricariidae). Zool. Verh. Leiden, 99 : 1-89, figs. $1-6$, pls. $1-18$, tabs. $1-20$, diagrams $1-19$.

-, 1969. Additional new species of Hypostomus Lacépède, 1803, from Surinam; with remarks on the apparent "gymnorhynchus-complex" (Siluriformes, Loricariidae). Beaufortia, 16 (215) : 119-136, figs. $1-5$, tabs. $1-2$, diagrams $1-19$.

Castelnau, F. De, 1855. Animaux nouveaux ou rares recueillis pendant l'expédition dans les parties centrales de l'Amérique du Sud, de Rio de Janeiro à Lima, et de Lima au Para; exécutée par ordre du gouvernement français pendant les années 1843 à 1847, sous la direction du comte Francis de Castelnau. - : i-xii, 1-106, pls. 1-50 (Bertrand, Paris).

Eigenmann, C. H. \& R. S. Eigenmann, 1889. Preliminary notes on South American nematognathi II. Proc. California Acad. Sci., (2) 1889 : 28-56.

- \& -, 1890. A revision of the South American nematognathi, or catfishes. Occ. Pap. California Acad. Sci., 1 : $1-508$, figs. $1-57,1$ map.

Gronovius, L. T., 1754. Museum ichthyologicum, sistens piscium indigenorum \& quorumdam exoticorum, etc., 1 : i-x, $1-70$, pls. $1-4$.

,- 1763 . Zoophylacii Gronoviani fasciculus primus exhibens animalia quadrupeda, amphibia atque pisces, etc., 1 : i-iv, 1-136, pls. 1-13.
Gronovius, L. T. (J. E. Gray, editor), 1854. Catalogue of fish collected and described by Laurence Theodore Gronow, now in the British Museum: i-vii, 1-196.

INTERNATIONAL CODE, 1964. International Code of Zoological Nomenclature adopted by the XV International Congress of Zoology: i-xix, 1-176.

LACÉPÈDE, C. (B. G. E.), 1803. Histoire naturelle des poissons, 5 : i-lxviii, $1-803,1$ fig., pls. $1-21$ (Plassan, Paris).

Linnaeus, C., 1754. Museum S. R. M. Adolphi Friderici Regis Suecorum ... in quo animalia rariora imprimis, et exotica ... describuntur et determinantur, Latine et Suecice, etc., : i-xxx, 1-96, 1-8, pls. 1-33.

,- 1758 . Systema naturae per regna tria naturae, etc. (ed. 10), $1: 1-824$.

Linnaeus, C. (J. F. Gmelin, editor), 1789. Systema naturae per regna tria naturae, etc. (ed. 13), 1 (3) : 1033-1516 (Lipsiae).

MeEs, G. F., 1967. Freshwater fishes of Surinam: The genus Heptapterus (Pimelodidae). Zool. Meded. Leiden, 42 (20): $215-229$, figs. $1-4$.

MENEZES, R. Simões DE, 1949. Incubação labial de ovos pelo macho de "Loricaria typus" Bleeker, da Lagoa do peixe, Piaui, Brasil (Actinopterygii, Loricariidae, Loricariinae). Rev. Brasil. Biol., 9 (3) : 381-387, figs. $1-3$, tab. 1 .

NiJssen, H., 1970. Revision of the Surinam catfishes of the genus Corydoras Lacépède, 1803 (Pisces, Siluriformes, Callichthyidae). Beaufortia, 18 (230): 1-75, figs. $1-40$, tab. 1 .

NiJsSEN, H. \& I. J. H. IsbrüCKer, 1967. Notes on the Guiana species of Corydoras Lacépède, 1803, with descriptions of seven new species and designation of a neotype for Corydoras punctatus (Bloch, 1794) (Pisces, Cypriniformes, Callichthyidae). Zool. Meded. Leiden, 42 (5) : $21-50$, figs. $1-4$, pls. $1-5$.

- \& -, 1968. Gymnotus carapo and G. anguillaris (syn.: G. coropinae), two often confused species of gymnotid fishes (Pisces, Cypriniformes). Beaufortia, 15 (203) : 161-168, 1 fig., tab. 1.

REgAN, C. T., 1904. A monograph of the fishes of the family Loricariidae. Trans. zool. Soc. London, 17 (3) : 191-350, pls. 9-21.

SEBA, A., 1758. Locupletissimi rerum naturalium thesauri accurata descriptio et iconibus artificiosissimis expressio, etc., 3 : (22, unnumbered), $1-212$, pls. $1-116$. 
STEINDACHNER, F., 1879. Uber einige neue und seltene Fisch-Arten aus den k. k. zoologischen Museen zu Wien, Stuttgart und Warschau, 6. Uber einige Arten der Gattungen Loricaria, Hypoptopoma und Anacyrtus aus dem Amazonen-Strome. Denkschr. kais. Akad. Wiss., mathem.-naturwiss. Cl., $41: 1-52$, pls. $1-9$.

-, 1882. Beiträge zur Kenntniss der Flussfische Südamerikas, 4. Bericht über eine Sammlung von Fischen aus dem Huallaga in dem Besitze des $\mathbf{k}$. zoologischen Museums in Dresden. Denkschr. kais. Akad. Wiss., mathem.-naturwiss. Cl., 46 : 1-44, pls. 1-7.

StrgChel, J. W. B. VAN DER, 1946. South American nematognathi: $1-204$, figs. $1-2$, tabs. $1-3$ (Thesis; E. J. Brill, Leiden). [Issued also in 1947: The South Ame- rican nematognathi of the museums at Leiden and Amsterdam. Zool. Meded. Leiden, 27 : 1-204, figs. 1-2, tabs. 1-3].

SwaInson, W., 1839. The natural history of fishes, amphibians, \& reptiles, or monocardian animals, 2 : (i-vi), 1-452, figs. 1-135 (Longman, Brown, Green \& Longmans, London).

Vaillant, L., 1880. Synopsis des especes de Siluridae recueillies par M. le Dr. Jobert, à Calderon (HauteAmazone). Bull. Soc. philomath. Paris, (7) 4: 150159.

Wheeler, A. C., 1958. The Gronovius fish collection: a catalogue and historical account. Bull. B. M. (N. H.), (Hist.) 1 (5) : 187-249, pls. 26-34. 